\title{
Penguatan Kesadaran Hukum Perlindungan Anak \\ BAgI GURU MADRASAH DINIYAH TAKMILIYAH DAN PONDOK \\ Pesantren AnaK-Anak se Kabupaten Blora Jawa Tengah
}

\section{Ali Imron, Supangat, Noor Rosyidah ${ }^{1}$}

\begin{abstract}
Abstrak: Terdapat beberapa kasus kekerasan anak yang melibatkan guru. Keterbatasan pemahaman para guru Madrasah Diniyah Takmiliyah dan Pondok Pesantren AnakAnak terhadap regulasi perlindungan anak berdampak terhadap kasus criminal justis yang melibatkan para guru.

Guru madrasah terkadang mempunyai perspektif lain terhadap tata hubungan murid dan guru ketika proses belajar mengajar. Oleh karena itu perlu diberikan kesempatan kepada para guru madrasah untuk memperoleh penguatan pendidikan kesadaran hukum perlindungan anak.

Alasan memilih guru Madrasah Diniyah Takmiliyah dan Pondok Pesantren Anak-Anak sebagai dampingan di antaranya adalah 1)mereka dalam beraktifitas kesehariannya berinteraksi dengan peserta didik yang usianya masuk kategori anak-anak, 2)mereka kurang mempunyai pemahaman yang cukup tentang hukum, 3)peran sosial guru madrasah mempengaruhi sistem tata perilaku masyarakat dan peserta didik.

Metode yang digunakan adalah ceramah, diskusi kelompok, dan studi kasus untuk mencari solusi pemecahannya.Hasil akhir dari kegiatan pengabdian ini adalah terdapat peningkatan pemahaman dan pengetahuan para guru terhadap regulasi tentang perlindungan anak. Hal ini dibuktikan dengan adanya peningkatan scor tes hasil evaluasi yaitu nilai rata-rata dari 3,7 menjadi 7,9 dari total score 10.
\end{abstract}

Kata Kunci: hukum, anak, guru, madrasah, perlindungan, pendidikan.

1 Tim Pengabdian kepada Masyarakat, Fakultas Syariah UIN Walisongo Semarang, PengabdianMasyarakatberbasisIlmu SyariahdanHukum(PM-SH) yang dibiayai oleh Diktis Kemenag RI Tahun 2015. 


\section{PENDAHULUAN}

Pemberitaan di media massa baik media cetak ataupun elektronik tentang kasus-kasus perbuatan melawan hukum dengan korban anak-anak sejak tahun 2013 sampai saat ini masih ramai. Ada beberapa kasus yang melibatkan guru sebagai terlapor dan bahkan sudah menjadi terdakwa dan tersangka di pengadilan.Sebagian dari mereka sudah menjalani putusan vonis pengadilan atas sangkaan pidana atas perbuatan yang telah dilakukannya.

Para guru yang berurusan dengan hukum perlindungan anak tidak sepenuhnya memahami batasan-batasan hukum tentang perbuatan apa yang boleh dilaksanakan dan perbuatan apa yang tidak boleh dilaksanakan terhadap anak-anak didiknya. Keterbatasan pengetahuan dan pemahaman para guru tersebut terhadap undang-undang perlindungan anak berdampak serius terhadap banyaknya kasus criminal justis yang melibatkan para guru.

Di satu sisi, para guru Madrasah Diniyah Takmiliyah dan Pondok Pesantren Anak-Anak yang mempunyai basic keilmuan keagamaan terkadang mepunyai perspektif lain ketika memahami tata hubungan murid dan guru ketika proses pembelajaran berlangsung. Hubungan murid dan guru dipahami sebagai hubungan antara seorang guru yang sedang 'menggembleng' anak agar anak kelak menjadi anak yang soleh solehah dan ilmunya bermanfaat.Terkadang murid diperlakukan kurang 'manusiawi' oleh guru hanya alasan untuk mendidik tata krama. Guru biasa memberikan hukuman pada murid-muridnya ketika murid melakukan perbuatan yang tidak sepatutnya dilakukan. Hukumanhukuman tersebut bisa berupa 'menjewer' (menarik telinga), 'nylentik' (memukul telinga dengan jari tangan), mencubit, memukul tangan dengan 'sulak' (alat pembersih debu), dan hukuman-hukuman lain yang nampak sudah biasa dilaksanakan.Akan tetapi terkadang tindakan-tindakan para guru tersebut menyebabkan orang tua murid tidak terima dan melaporkan ke aparat penegak hukum.Dari sinilah muncul permasalahan-permasalahan hukum yang harus dihadapi para guru tersebut.

Munculnya permasalahan-permasalahan hukum yang dihadapi para guru tersebut, disebabkan oleh: pertama, keterbatasan pengetahuan dan pemahaman para guru terhadap hukum perlindungan anak. Kedua, tidak atau belum ada kesempatan bagi para guru tersebut untuk mendapatkan penguatan pendidikan kesadaran hukum perlindungan anak. Ketiga, kurangnya pemahaman para guru tersebut tentang hukum perlindungan anak dikhawatirkan akan berpotensi pada 
pelanggaran hukum atau munculnya perbuatan melawan hukum baik disengaja maupun tanpa sengaja karena ketidaktahuannya.

Permasalahan prioritas yang yang harus ditangani segera yaitu perlu diberikan kesempatan kepada para guru Madrasah Diniyah dan Pondok Pesantren Anak-Anak tersebut untuk memperoleh penguatan pendidikan kesadaran hukum perlindungan anak baik melalui pelatihan atau penyuluhan atau kursus singkat yang terstruktur.

\section{Alasan Memilih Subjek Dampingan}

Kegiatan penyuluhan atau kursus singkat peguatan pendidikan kesadaran hukum perlindungan anak ini melibatkan peserta sebanyak 120 (seratus dua puluh) orang yang terdiri dari para guru TPQ (Taman Pendidikan Al Quran), guru MADIN (Madrasah Diniyah) Takmiliyah dan guru Pondok Pesantren Anak-Anak yang berada di wilayah 14 (empat belas) kecamatan se kabupaten Blora Jawa Tengah. Alasan memilih mereka sebagai subjek dampingan di antaranya adalah

Pertama, mereka para guru dalam beraktifitas kesehariannya berinteraksi dengan peserta didik yang usianya masuk kategori anak-anak, dan mereka tidak atau belum mempunyai pemahaman yang cukup tentang hukum perlindungan anak sehingga dikhawatirkan akan berhadapan dengan problematika perbuatan melawan hukum.

Kedua, eksistensi para guru tersebut yang tergabung dibawah naungan FKDT (Forum Komunikasi Madrasah Diniyah Takmiliyah) kabupaten Blora.Peran sosial yang dimainkan oleh para guru tersebut dapat mempengaruhi sistem tata perilaku masyarakat umumnya dan para peserta didik khususnya. Oleh karena itu dengan memberikan pengetahuan yang cukup tentang kesadaran hukum perlindungan anak kepada para guru tersebut juga akan berdampak secara positif terhadap tata perilaku masyarakat.

\section{Kondisi Dampingan Saat Ini}

Kondisi dampingan kegiatan penyuluhan atau kursus singkat peguatan pendidikan kesadaran hukum perlindungan anak ini dapat pengabdi diskripsikan sebagai berikut:

Pertama, pengabdi bermitra atau bekerjasama dengan stakeholders yaitu pengurus FKDT (Forum Komunikasi Madrasah Diniyah Takmiliyah) kabupaten Blora, yang notabenenya menaungi lembaga-lembaga pendidikan Madrasah 
Diniyah Takmiliyah dimana para guru peserta kegiatan pengabdian ini melaksanakan tugas sebagai guru. Lokasi pengabdian dengan kampus IAIN Walisongo berjarak +/- 105 (seratus lima) km. Pelaksanaan kegiatan pengabdian ini juga melibatkan beberapa mahasiswa UIN Walisongo yang sedang melaksanakan Kuliah Kerja Nyata (KKN) di kabupaten Blora.

Kedua, pengetahuan atau pemahaman para guru TPQ (Taman Pendidikan Al Quran), guru MADIN (Madrasah Diniyah) Takmiliyah dan guru Pondok Pesantren Anak-Anak yang berada di wilayah kabupaten Blora, terhadap hukum atau peraturan perundangan tentang perlindungan anak masih jauh dari harapan. Para guru tersebut kurang mendapatkan kesempatan untuk belajar dan mengkaji lebih dalam lagi tentang hukum perlindungan anak yang diatur dalam regulasi di Indonesia.Para guru tersebut nyaris belum atau tidak memahami aturan hukum tentang perlindungan anak. Hal ini apabila dibiarkan terus menerus akan sangat beresiko yang tidak menguntungkan bagi mereka dan juga anak didiknya.

Ketiga, hampir semua guru tersebut tidak ada yang berbasis sarjana hukum, mayoritas berpendidikan dari pesantren salafiyyah dan sedikit yang lulusan perguruan tinggi agama dan atau sebagian dari mereka sedang menyelesaikan kuliah.

\section{Kondisi Dampingan Yang Diharapkan}

Kondisi dampingan yang diharapkan oleh kegiatanpenyuluhan atau kursus singkat peguatan pendidikan kesadaran hukum perlindungan anak ini adalah terciptanya pemahaman yang utuh oleh para guru TPQ (Taman Pendidikan Al Quran), guru MADIN (Madrasah Diniyah) Takmiliyah dan guru Pondok Pesantren Anak-Anaktentang hukum perlindungan anak dan mampu mengimplementasikan dalam beraktifitas sehari-hari sebagai guru.

\section{Strategi dan Metode Yang Dilakukan}

Kegiatan pengabdian ini berupa penyuluhan atau kursus singkat peguatan pendidikan kesadaran hukum perlindungan anak. Untuk mendapatkan kondisi dampingan yang diharapkan oleh kegiatan pengabdian ini, maka pengabdi menggunakan strategi berupa kerjasama dengan stakeholders yaitu pengurus FKDT (Forum Komunikasi Madrasah Diniyah Takmiliyah) kabupaten 
Blora.Kerjasama kegiatan ini meliputi perencanaan kegiatan, pelaksanaan kegiatan, dan evaluasi hasil kegiatan.

Adapun tahapan-tahapannya adalah sebagai berikut:Pertama, pendaftaran peserta pelatihan berdasarkan hasil koordinasi dan rekomendasi FKDT (Forum Komunikasi Madrasah Diniyah Takmiliyah) kabupaten Blora, sebanyak 120 (seratus dua puluh) orang calon peserta berhasil diidentifikasi dan menjadi peserta kegiatan penyuluhan atau kursus singkat peguatan pendidikan kesadaran hukum perlindungan anak.

Kedua, sebelum mengikuti pelatihan dilakukan tes penjajakan atau tes uji coba kemampuan peserta terhadap pemahaman hukum perlindungan anak.Calon peserta terbagi dalam 4 (empat) cluster kelompok belajar.

Ketiga, hasil dari tes penjajakan tersebut akan dijadikan dasar bagi instruktur dalam pengelolaan kelas pelatihan.

Keempat, setelah mengikuti pelatihan semua peserta mengikuti tes akhir untuk mengukur sejauh mana penyerapan dan pemahaman peserta terhadap materi pelatihan.Hal ini penting untuk mengevaluasi keberhasilan kegiatan pelatihan ini dari aspek akademik.

Kelima, melakukan evaluasi secara menyeluruh atas kegiatan pengabdian ini guna mendapatkan penilaian keberhasilan kegiatan ini dan menyusun rekomendasi untuk program pengabdian sejenis yang akan dilakukan.

Adapun metode yang digunakan dalam kegiatan pengabdian ini adalah: Pertama, metode ceramah yaitu nara sumber menyampaikan materi-materi tentang hukum perlindungan anak perspektif peraturan perundangan di Indonesia dan perspektif hukum Islam.

Kedua, metode diskusi yaitu nara sumber memandu diskusi tentang studi kasus dan problematika implementasi peraturan perundangan tentang perlindungan anak di masyarakat khususnya di lingkungan lembaga pendidikan baik formal maupun non formal yang peserta didiknya masih berusia anak-anak.

Ketiga, metode evaluasi yaitu pengabdi mempersiapkan bahan-bahan evaluasi tentang materi hukum perlindungan anak.Metode ini pengabdi gunakan untuk mengukur tingkat penguasaan dan pemahaman peserta terhadap hukum perlindungan anak baik sebelum kegiatan pengabdian maupun setelah kegiatan pengabdian. 


\section{LANDASAN TEORI}

\section{Pengertian Dan Dasar Hukum Perlindungan Anak}

Menurut undang-undang Nomor 23 Tahun 2002 tentang perlindungan anak, yang dimaksud dengan anak adalah seseorang yang belum berusia 18 (delapan belas) tahun, termasuk anak yang masih dalam kandungan (Pasal 1 item 1). Orang tua wajib memberikan perlindungan terhadap anak yang belum mencapai usia 18 tahun termasuk terhadap janin yang berada di kandungan ibunya.

Di dalam Undang-Undang Nomor 3 Tahun 1997 tentang Pengadilan Anak dinyatakan bahwa anak adalah orang yang di dalam perkara anak nakal telah mencapai umur 8 (delapan) tahun tetapi belum mencapai umur 18 (delapan belas) tahun dan belum pernah kawin.

Sedangkan menurut undang-undang Nomor 4 Tahun 1979 tentang kesejahteraan anak, yang dimaksud dengan anak adalah seseorang yang belum mencapai umur 21 (dua puluh satu) tahun dan belum pernah kawin. Ini artinya meskipun usia anak belum mencapai 21 tahun tetapi sudah kawin, maka dalam hal kesejahteraan menjadi tanggungjawab sepenuhnya anak tersebut.

Rumusan anak di dalam Kitab Undang-Undang Hukum Perdata (KUH Per) dirumuskan dengan kalimat orang yang belum dewasa. Menurut Pasal 330 KUH Perorang yang belum dewasa adalah mereka yang belum mencapai umur genap 21 (dua puluh satu tahun) dan tidak lebih dahulu telah kawin.

Anak menurut undang-undang perlindungan anak diklasifikasikan menjadi beberapa macam, yaitu:

1. Anak terlantar yaitu anak yang kebutuhannya sehari-hari tidak dapat terpenuhi secara wajar, baik fisik, mental, spiritual, maupun sosial.

2. Anak penyandang cacat yaitu anak yang pertumbuhan dan perkembangannya tidak wajar karena mengalami gangguan fisik atau mental.

3. Anak yang memiliki keunggulan tertentu yaitu anak yang mempunyai kecerdasan luar biasa, atau yang memiliki potensi dan atau bakat istimewa.

4. Anak angkat yaitu anak yang haknya dialihkan dari lingkungan kekuasaan keluarga, wali yang sah, atau orang lain yang bertanggung jawab atas perawatan, pendidikan, dan membesarkan anak tersebut, ke dalam lingkungan keluarga orang tua angkatnya berdasarkan putusan atau penetapan pengadilan. 
5. Anak asuh yaitu anak yang diasuh oleh seseorang atau lembaga pengasuhan atau panti asuhan, untuk diberikan bimbingan, pemeliharaan, perawatan, pendidikan, dan kesehatan, karena orang tuanya tidak mampu mengasuh anak dan tidak mampu menjamin tumbuh kembang anak secara wajar di masyarakat.

Hukum Islam memberikan batasan anak dengan kalimat baligh secara kualitatif. Sebagian ulama menerjemahkan rumusan baligh tersebut dengan batasan usia secara kuantitatif. Firman Allah dalam al Quran surat al Nisa (4) ayat 6:

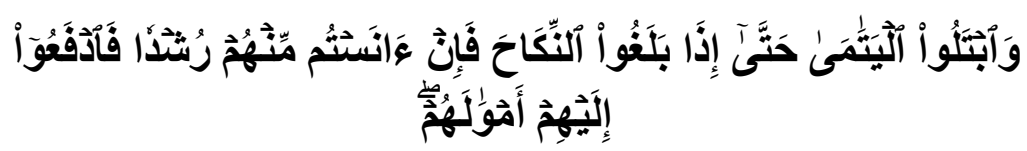

Artinya: "Dan wijlah anak yatim itu sampai mereka cukup umur untuk kawin. Kemudian jika menurut pendapatmu mereka telah cerdas (pandai memelihara harta), maka serabkanlah kepada mereka harta-hartanya."

Para ulama ushul fiqh memahamikalimat 'cukup umur' dalam ayat tersebutdengan ibtilam atau seseorang telah bermimpi dengan mengeluarkan mani untuk pria dan telah keluar haid untuk wanita. Anak dipahami sebagai seseorang yang belum cukup umur atau belum baligh.

Imam as Syafi $i$, sebagaimana dikutip oleh Imam Jalaluddin as Suyuthidalam bukunya Tafsir Jalalain, memberikan batasan baligh yaitu:

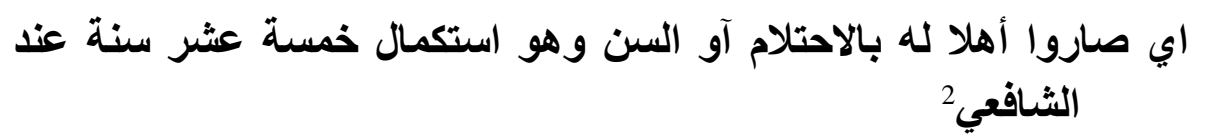

Artinya: Mereka jadi cakap karena telah mimpi keluar mani atau telah cukup umur yaitu telah sempurna lima belas tabun menurut as Syafi i $i$.

2 Al Imam Jalaluddin al Mahaly dan Jalaluddin as Suyuthi, Tafsir al Qur an al Karim, Juz I, Beirut: Daar al Fikr, 1998, halaman 98 
Dengan demikian, Imam as Syafi i memberikan batasan ketentuan anak dengan dua alternatif pilihan yaitu (1) ibtilam (بالاحتلام) atau mimpi basah atau mimpi sampai mengeluarkan air mani, dan (2) dengan usia (السن), yaitu 15 tahun.

Dalam lapangan hukum keperdataan, Wahbah al Zuhayli memberikan batasan usia seorang anak yang masuk kriteria sudah mumayyiz yaitu usia anak telah genap usia 7 tahun. Ia mengemukakan:

\section{سن التمييز وهو تمام سن السابع 3. .}

Artinya "usia anak yang tamyiz yaitu usia anak yang telah sempurna tujub tabun"

Secara umum, ciri-ciri baligh di antaranya adalah (1) anak (laki-laki atau perempuan) telah bermimpi sampai mengeluarkan air mani (احتلام), (2) datangnya haid bagi anak perempuan, (3) anak mencapai umur 15 tahun (jumhur ulama).

Batasan baligh menurut Imam Abu Hanifah yaitu anak telah mencapaiumur 18 tahun (laki-laki) dan 17 tahun (perempuan).Imam Malik, sebagaimana dikutip oleh al Qurtubi ${ }^{4}$ dan al Dardiri ${ }^{5}$ memberikan batasan baligh yaitu umur 18 tahun (laki-laki dan perempuan) atau genap 17 tahun memasuki usia 18 tahun.

Baligh menurut ulama Hanafiyyah yaitu serendah-rendahnya umur 12 tahun (laki-laki) dan umur 9 tahun (perempuan). Ulama Hanafiyyah juga memberikan batasan baligh yaitu ibtilam (mimpi keluar mani dalam keadaan tidur atau terjaga), keluarnya air mani karena bersetubuh atau tidak, dan atau mampu menghamili wanita (احبال المراه). Baligh bagi perempuan adalah haid, usia minimal 9 tahun dan atau kehamilan. ${ }^{6}$

Kriteria baligh menurut Mazhab Malikiyyah ada 7 macam.Lima kriteria bagi laki-laki dan perempuan, sedangkan yang dua kriteria khusus bagi

${ }^{3}$ Wahbah al Zuhayli,Figh Islam wa Adillatuh, Beirut: Daar al Fikr, 1999, halaman 121

${ }^{4}$ Abu Abdillah Muhammad bin Ahmad al Qurthubhi, al Jami`li Abkam al Qur`an, Jilid V, Beirut: Daar al Fikr, t.thn., halaman 37

${ }^{5} \mathrm{Al}$ Dardiri, al Syarb al Kabir Hasiyah Dasuki, Jilid III, Mesir: Al Babi al Halabi, t.thn., halaman 393

${ }^{6}$ Ibn Abidin, Hasyiyah Rad al Mukhtar ala Dur al Mukhtar, Jilid V, Mesir: Al Babi al Halabi, t.thn., halaman 107 
perempuan.Kriteria baligh khusus perempuan adalah (1) haid, dan (2) hamil.Baligh bagi laki-laki dan perempuan adalah (1) keluar air mani baik keadaan tidur atau terjaga, (2) tumbuhnya rambut di sekitar kemaluan, (3) tumbuhnya rambut di ketiak, (4) indra penciuman hidung menjadi peka, dan (5) perubahan pita suara. Secara kuantitatif, Malikiyah memberikan batasan baligh yaitu umur genap 18 tahun atau usia genap 17 tahun memasuki usia 18 tahun. ${ }^{7}$ Wahbah al Zuhayli8 juga berpendapat hal yang sama dengan Malikiyah tersebut.

Madzhab Syafi iyyah, sebagaimana dikutib olehAl Sairozi ${ }^{9}$ dan al Khatib $^{10}$, berpendapat bahwa baligh secara umum (laki-laki atau perempuan) ditandai dengan (1) umur genap 15 tahun qomariyah, (2) atau keluarnya air mani, (3) atau tumbuhnya rambut di sekitar kemaluan. Madzhab Syafi iyyah tidak sependapat jika rambut di ketiak dijadikan sebagai dasar ukuran baligh.Tandatanda baligh bagi perempuan yaitu (1) haid, dan atau (2) hamil.

Dari paparan tersebut di atas penulis simpulkan bahwa secara kualitatif, anak yaitu seseorang yang belum dewasa atau yang belum baligh termasuk janin yang masih di dalam kandungan dan ia belum pernah menikah. Sedangkan secara kuantitatif, penulis sepakat bahwa anak yaitu seseorang yang belum mencapai usia 18 tahun atau setingkat dengan lulus kelas 3 madrasah aliyah (MA/SMU) secara normal termasuk janin yang masih di dalam kandungan.

Di dalam undang-undang Nomor 23 Tahun 2002 tentang perlindungan anak dinyatakan bahwa yang dimaksud dengan perlindungan anak adalah segala kegiatan untuk menjamin dan melindungi anak dan hak-haknya agar dapat hidup, tumbuh, berkembang, dan berpartisipasi, secara optimal sesuai dengan harkat dan martabat kemanusiaan, serta mendapat perlindungan dari kekerasan dan diskriminasi.

Berdasarkan pengertian dalam undang-undang tersebut, penulis simpulkan bahwa dalam kalimat perlindungan terdapat muatan makna yaitu 1)pertama, menjamin dan melindungi, 2)kedua, harkat dan martabat kemanusiaan, dan 3)ketiga, anti kekerasan dan anti diskriminasi.

Status dan kedudukan anak sangat terhormat perspektif hukum Islam.Semua anak statusnya adalah fitrah.Siapapun orang tuanya dan apapun

${ }^{7}$ Al Dardiri, Al Syarh al Kabir Hasyiyah Dasuki, Jilid III,Mesir: Matba ah al Babi al Halabi, t.thn., halaman 293.

8 Wahbah al Zuhayli, Op.Cit., Jilid V, halaman 423

9 Abu Ishak as Sairozi, Al Muhadzab, Juz I, Mesir: Mathba ah al Babi al Halabi., t.thn., halaman 330

${ }^{10}$ al Syarbini al Khatib, Mughni al Mubtaj Syarh al Minhaj, Juz II, Mesir: Mathba ah al Babi al Halabi., t.thn., halaman 166 
keimanan orang tuanya, bahkan anak yang lahir dari hasil perbuatan zina juga termasuk fitrah.Anak tidak menanggung dosa yang dilakukan oleh orang tua biologisnya.Kata fitrah di sini dipahami bahwa anak tersebut suci dari segala hal dosa dan anak tersebut terlahir sesuai dengan karakter dasar keinginan manusia yaitu sejahtera lahiriyah maupun batiniyah.

Di sinilah arti penting pengasuhan terhadap anak. Pola perilaku dan suasana sosial pribadi pengasuh akan sangat mempengaruhi perkembangan jiwa mental dan tumbuh berkembangnya anak. Anak tidak hanya membutuhkan asupan gizi untuk memenuhi kebutuhan fisik atau jasmaninya saja, ia juga membutuhkan asupan gizi berupa nilai-nilai spiritual untuk memenuhi kebutuhan ruhaninya.

Firman Allah di dalam al Quran surat al Baqarah ayat 233 yang artinya: "Dan hendaknya para ibu menyusui anak-anaknya selama dua tahun penuh bagi dia yang menginginkan untuk menyempurnakan susuan". Potongan ayat ini memerintahkan kepada orang tua agar memperhatikan secara serius tentang arti pentingnya menyusui anak dengan air susu ibu (ASI) secara maksimal yaitu genap dua tahun.

Potongan ayat 233 berikutnya adalah "dan wajib bagi orang tua atau ayah memenuhi kebutuhan pangan dan sandang ibu yang menyusui". Ayah atau suami harus mengambil peran dalam upaya untuk memberikan perlindungan yang terbaik terhadap anaknya dengan cara memenuhi kebutuhan asupan gizi yang terbaik dan berkualitas untuk ibu atau istri yang sedang menyusui. Suami atau ayah juga harus memberikan kebutuhan sandang papan sesuai dengan kadar kemampuannya. Demikianlah arti penting perlindungan orang tua terhadap anak yang masih dalam masa menyusui.

\section{Hubungan Orang Tua, Wali, Dan Anak}

Keluarga merupakan unit terkecil dalam masyarakat.Unsur keluarga terdiri dari suami isteri, atau suami isteri dan anaknya, atau ayah (suami) dan anaknya, atau ibu (isteri) dan anaknya.Unsur-unsur tersebut membentuk satu kesatuan yang disebut dengan istilah keluarga.

Yang dimaksud dengan orang tua adalah terdiri dari ayah, ibu kandung, ayah bersama ibu kandung, ayah bersama ibu tiri, dan atau ayah bersama ibu angkat.Orang tua berkewajiban mengasuh anak sampai anak tumbuh berkembang dewasa.Apabila karena sesuatu hal sehingga orang tua tidak dapat melaksanakan pengasuhan anak, maka hak asuhnya dapat dipindahkan atau beralih kepada keluarga. Dan apabila karena sesuatu hal sehinga keluarga tidaka 
dapat menunaikan kewajiban tersebut maka pengasuhan anak diserahkan kepada wali.

Orang tua berkewajiban dan bertanggung jawab penuh terhadap terwujudnya penyelenggaraan perlindungan anak. Adapun kewajiban dan tanggungjawab orang tua tersebut yaitu 1)pertama, mengasuh, memelihara, mendidik, dan melindungi anak, 2)kedua, menumbuhkembangkan anak sesuai dengan kemampuan, bakat, dan minatnya, dan 3)ketiga, mencegah terjadinya perkawinan pada usia anak-anak.

Anak mempunyai hak-hak yang harus dilindungi dalam kegiatan pengasuhan. Hak-hak anak dalam pengasuhan sebagaimana diatur di dalam Pasal 4 sampai Pasal 18 undang-undang perlindungan anak, yaitu:

1) Hak untuk dapat hidup, tumbuh, berkembang, dan berpartisipasi secara wajar sesuai dengan harkat dan martabat kemanusiaan, serta mendapat perlindungan dari kekerasan dan diskriminasi.

2) Hak atas suatu nama sebagai identitas diri dan status kewarganegaraan. Nama yang diberikan kepada anak hendaknya nama yang baik.

3) Hak untuk beribadah menurut agamanya, berpikir, dan berekspresi sesuai dengan tingkat kecerdasan dan usianya, dalam bimbingan orang tua.

4) Hak untuk mengetahui orang tuanya, dibesarkan, dan diasuh oleh orang tuanya sendiri.

5) Hak memperoleh pelayanan kesehatan dan jaminan sosial sesuai dengan kebutuhan fisik, mental, spiritual, dan sosial.

6) Hak memperoleh pendidikan dan pengajaran dalam rangka pengembangan pribadinya dan tingkat kecerdasannya sesuai dengan minat dan bakatnya.

7) Hak memperoleh pendidikan luar biasa bagi anak yang menyandang cacat, dan hak mendapatkan pendidikan khusus bagi anak yang memiliki keunggulan.

8) Hak menyatakan dan didengar pendapatnya, menerima, mencari, dan memberikan informasi sesuai dengan tingkat kecerdasan dan usianya demi pengembangan dirinya sesuai dengan nilai-nilai kesusilaan dan kepatutan.

9) Hak untuk beristirahat dan memanfaatkan waktu luang, bergaul dengan anak yang sebaya, bermain, berekreasi, dan berkreasi sesuai dengan minat, bakat, dan tingkat kecerdasannya demi pengembangan diri.

10) Hak memperoleh rehabilitasi, bantuan sosial, dan pemeliharaan taraf kesejahteraan sosial bagi anak yang menyandang cacat. 
11) Hak mendapat perlindungan dari perlakuan diskriminasi, eksploitasi baik ekonomi maupun seksual, penelantaran, kekejaman, kekerasan, dan penganiayaan, ketidakadilan dan perlakuan salah lainnya.

12) Hak untuk diasuh oleh orang tuanya sendiri, kecuali jika ada alasan dan atau aturan hukum yang sah menunjukkan bahwa pemisahan itu adalah demi kepentingan terbaik bagi anak dan merupakan pertimbangan terakhir.

13) Hak untuk memperoleh perlindungan dari penyalahgunaan dalam kegiatan politik, pelibatan dalam sengketa bersenjata, pelibatan dalam kerusuhan sosial, pelibatan dalam peristiwa yang mengandung unsur kekerasan, dan pelibatan dalam peperangan.

14) Hak memperoleh perlindungan dari sasaran penganiayaan, penyiksaan, atau penjatuhan hukuman yang tidak manusiawi.

15) Hak untuk memperoleh kebebasan sesuai dengan hukum. Penangkapan, penahanan, atau tindak pidana penjara anak hanya dilakukan apabila sesuai dengan hukum yang berlaku dan hanya dapat dilakukan sebagai upaya terakhir.

16) Hak untuk mendapatkan perlakuan secara manusiawi dan penempatannya dipisahkan dari orang dewasa.

17) Hak untuk memperoleh bantuan hukum atau bantuan lainnya secara efektif dalam setiap tahapan upaya hukum yang berlaku.

18) Hak untuk membela diri dan memperoleh keadilan di depan pengadilan anak yang objektif dan tidak memihak dalam sidang tertutup untuk umum.

19) Hak untuk dirahasiakan bagi anak yang menjadi korban atau pelaku kekerasan seksual atau yang berhadapan dengan hukum.

Anak juga memiliki kewajiban yang harus ia lakukan sebagai wujud tanggungjawab sosialnya sesuai dengan tingkat umur dan kecerdasan anak. Meskipun anak mempunyai banyak hak yang dilindungi oleh undang-undang, bukan berarti ia boleh berbuat seenaknya sendiri dan mengabaikan hak-hak orang lain yang ada di sekitarnya.

Adapun kewajiban anak menurut Pasal 19 undang-undang perlindungan anak yaitu 1)pertama, menghormati orang tua, wali, dan guru, 2)kedua, mencintai keluarga, masyarakat, dan menyayangi teman, 3)ketiga, mencintai tanah air, bangsa, dan negara, 4)keempat, menunaikan ibadah sesuai dengan ajaran agamanya, dan 5)kelima, melaksanakan etika dan akhlak yang mulia. 


\section{Prinsip-Prinsip Dasar Perlindungan Anak}

Perlindungan anak mempunyai tujuan untuk menjamin terpenuhinya hakhak anak agar dapat hidup, tumbuh, berkembang, dan berpartisipasi secara optimal sesuai dengan harkat dan martabat kemanusiaan, serta mendapat perlindungan dari kekerasan dan diskriminasi, demi terwujudnya anak Indonesia yang berkualitas, berakhlak mulia, dan sejahtera.

Agar tujuan perlindungan anak dapat direalisasikan maka segala aktifitas dan kegiatan pengasuhan anak harus memperhatikan prinsip-prinsip dasar hak anak. Terdapat prinsip-prinsip dasar hak-hak anak, yaitu:

a. Non diskriminasi;

Setiap anak mempunyai hak yang sama dengan anak yang lain secara fungsional dan proporsional. Orang tua, keluarga, wali atau pengasuh harus memperlakukan anak satu dengan anak yang lain dengan sikap perlakuan yang sama. Perlakuan yang sama terhadap anak ini bersifat kualitatif dan juga kuantitatif.

b. Kepentingan yang terbaik bagi anak;

Hampir semua orang tua sepakat dan menginginkan agar anaknya kelak menjadi anak yang terbaik dan sukses. Orang tua terkadang menginginkan agar anaknya menjadi anak yang penurut dan tidak membantah terhadap apa yang menjadi keinginan dan perintah orang tua, termasuk dalam menentukan arah pendidikan anak-anaknya. Orang tua tidak boleh egois dalam mengarahkan anak.

c. Hak untuk hidup, kelangsungan hidup, dan perkembangan; Anak merupakan amanat dan sekaligus anugerah dari Allah Tuhan Yang Maha Esa.Mungkin saja anak yang dilahirkan oleh isteri tidak sesuai dengan harapan suami, atau terkadang bahkan kelahiran anak tersebut justru tidak diharapkan. Suami isteri mengharapkan agar mempunyai anak laki-laki atau perempuan, dan ternyata ia lahir tidak sesuai dengan harapan.

Penghargaan terhadap pendapat anak.

Anak mempunyai hak untuk berbicara dan menyampaikan pendapat.Apapun pendapat anak harus didengar dan dihormati oleh siapapun yang ada di lingkungan anak tersebut termasuk orang tuanya. Ketika pendapat anak didengar dan dihargai maka diharapkan 
untuk selanjutnya anak dapat kreatif dan mempunyai ide-ide segar dan cerdas.

Prinsip dasar hak anak tersebut merupakan bagian dari hak asasi manusia yang wajib dijamin, dilindungi, dan dipenuhi oleh orang tua, keluarga, masyarakat, maupun pemerintah.Kewajiban pemenuhan hak dasar anak tersebut bersifat hierarki secara berurutan.

\section{Peran Pemerintah Dan Masyarakat}

Penyelenggaraan perlindungan anak merupakan tanggungjawab orang tua, keluarga, segenap lapisan masyarakat dan juga pemerintah.Orang tua mempunyai peran yang utama dalam penyelenggaraan perlindungan anak, kemudian secara berurutan diikuti oleh keluarga, masyarakat, dan pemerintah. Ketika orang tua dan keluarga tidak mampu dalam memberikan perlindungan terhadap anaknya maka peran masyarakat dan pemerintah sangat diharapkan dan menjadi tumpuan untuk kemaslahatan masa depan anak tersebut.

Peran pemerintah dalam penyelenggaraan perlindungan anak ini berupa memberikan dukungan sarana dan prasarana sehingga berbagai macam bentuk dan varian perlindungan anak dapat terlaksana dengan baik dan ideal.Pemerintah berkewajiban dan bertanggung jawab menghormati dan menjamin hak asasi setiap anak tanpa membedakan suku, agama, ras, golongan, jenis kelamin, etnik, budaya dan bahasa, status hukum anak, urutan kelahiran anak, dan kondisi fisik dan atau mental.

Dalam memberikan jaminan atas perlindungan dan kesejahteraan anak pemerintah harus tetap memperhatikan hak dan kewajiban orang tua, wali, atau orang lain yang secara hukum bertanggung jawab terhadap anak. Pemerintah harus tetap memberikan pengawasan terhadap semua elemen masyarakat dalam penyelenggaraan perlindungan anak.

Masyarakat harus ambil peran dalam penyelenggaraan perlindungan anak.Masyarakat yang dimaksud bisa berupa perseorangan, keluarga bukan keluarga anak, kelompok, organisasi sosial dan atau juga bisa organisasi kemasyarakatan.Setiap warga masyarakat dapat menyelenggarakan kegiatankegiatan kreatif untuk terwujudnya perlindungan anak.Peran masyarakat dapat berupa dukungan sarana dan prasarana, memberikan motifasi dan penghargaan. 


\section{OUT PUT DAMPINGAN}

Kegiatan karya pengabdian masyarakat ini berbentuk penyuluhan atau kursus singkatpeguatan pendidikan kesadaran hukum perlindungan anak.Kegiatan ini bekerjasama dengan stakeholder. Adanya stakeholders dalam kegiatan ini sangat membantu dalam perencanaan peserta kegiatan, pelaksanaan kegiatan dan evaluasi hasil kegiatan sehingga kegiatan dapat berjalan dengan baik dan lancar. Adapun stakeholder dalam kegiatan ini yaitu Pengurus FKDT (Forum Komunikasi Madrasah Diniyah Takmiliyah) kabupaten Blora yang notabene membawahi beberapa lembaga pendidikan di mana peserta dalam kegiatan ini adalah para guru lembaga pendidikan tersebut. Dipilihnya FKDT (Forum Komunikasi Madrasah Diniyah Takmiliyah) kabupaten Blora karena 1)FKDT ini memiliki banyak lembaga pendidikan keagamaan berupa Madrasah Diniyah Takmiliyah yang jumlah madrasahnya seratus lebih tersebar se kabupaten Blora; 2)Banyak guru yang bernaung di lembaga pendidikan tersebut belum sepenuhnya memahami peraturan perundangan tentang perlindungan anak; 3)Kabupaten Blora dijadikan sebagai lokasi Kuliah Kerja Nyata (KKN) UIN Walisongo Semarang, sehingga aktifitas pengabdian ini banyak terbantu dengan pelibatan mahasiswa peserta KKN sekaligus sebagai sarana pembelajaran bagi para mahasiswa tentang pengabdian masyarakat; dan 4)Pengurus FKDM kabupaten Blora siap bekerjasama untuk sukses terselenggaranya kegiatan pengabdian ini.

Peserta kegiatan ini sebanyak 120 (seratus dua puluh) orang yang terdiri dari guru Taman Pendidikan al Quran (TPQ), guru Madrasah Diniyah (MADIN) Takmiliyah, dan guru Pondok Pesantren Anak-Anak se kabupaten Blora. Kegiatan penyuluhan atau kursus singkat peguatan pendidikan kesadaran hukum perlindungan anak ini telah dilaksanakan pada hari Selasa, tanggal 22 September 2015, mulai jam 07.00 sampai dengan jam 16.55 WIB, bertempat di Gedung PCNU kabupaten Blora d/a Jln. Nusantara No 48 kelurahan Jetis kabupaten Blora. Dipilihnya lokasi kegiatan di Gedung PCNU ini karena kantor tersebut memiliki fasilitas yang representatif untuk mendukung terlaksananya kegiatan ini dan lokasi kantor PCNU berada di tengah-tengah wilayah kabupaten Blora sehingga memudahkan jangkauan kehadiran para peserta kegiatan ini.

Diskusi studi kasus dan problematika implementasi peraturan perundangan tentang perlindungan anak di masyarakat khususnya pada lingkungan lembaga pendidikan baik formal maupun non formal yang peserta didiknya masih berusia anak-anak ini sangat menarik diikuti oleh para peserta.Suasana sangat hidup dan masing-masing peserta sangat aktif 
menceritakan berbagai hal problematika yang ada di lingkungan lembaga pendidikan masing-masing.Setelah identifikasi problematika kemudian dicari solusi pemecahannya agar sesuai degan hukum yang berlaku di Indonesia. Setelah sesi diskusi ini selesai kemudian diadakan review atas materi-materi yang telah didapatkan sejak pagi. Review materi ini sangat penting untuk merefresh penyerapan peserta atas materi kegiatan yang telah disampaikan oleh para narasumber guna membantu kesiapan peserta untuk mengerjakan evalusi penyerapan materi melalui uji tes akhir.

Sebelum pelaksanaan kegiatan penyuluhan atau kursus singkat peguatan pendidikan kesadaran hukum perlindungan anak ini telah dilakukan evaluasi atau pretest atau tes ujicoba terhadap semua peserta.Maksud evaluasi pretest ini adalah untuk mengukur tingkat penguasaan dan pemahaman peserta terhadap hukum perlindungan anak khususnya undang-undang Nomor 23 Tahun 2002.

Hasil evaluasi pretest menunjukkan bahwa tingkat pemahaman peserta terhadap undang-undang Nomor 23 Tahun 2002 tentang perlindungan anak sangat rendah yaitu nilai rata-rata yang diperoleh score 3,7 dari total score 10 . Hasil dari pretest ini dijadikan dasar bagi narasumber atau instruktur dalam pengelolaan kelas penyuluhan atau kursus singkat ini.

Semua peserta mengikuti tes akhir pelatihan untuk mengukur sejauh mana penyerapan dan pemahaman peserta terhadap materi pelatihan.Hal ini penting untuk mengevaluasi keberhasilan kegiatan pelatihan ini dari aspek akademik. Hasil evaluasi tes akhir menunjukkan bahwa tingkat pemahaman peserta terhadap undang-undang Nomor 23 Tahun 2002 tentang perlindungan anak mengalami peningkatan yang cukup signifikan yaitu nilai rata-rata yang diperoleh score 7,9 dari total score 10 .

Secara umum pelaksanaan kegiatan penyuluhan atau kursus singkat peguatan pendidikan kesadaran hukum perlindungan anak ini berjalan relatif baik dan lancar. Meskipun demikian terdapat beberapa hambatan yang mempengaruhi secara tidak langsung terhadap jalannya kegiatan ini, di antaranya yaitu: 1)Jumlah kuota peserta kegiatan ini tidak sebanding dengan jumlah para guru di wilayah kabupaten Blora. Penentuan guru siapa saja yang berkesempatan mengikuti kegiatan ini terjadi perbedaan pendapat.Ada usulan agar diprioritaskan guru-guru TPQ dan sebagian guru Madrasah Diniyah Takmiliyah, kalau masih ada sisa kuota baru diikutkan guru Pondok Pesantren Anak-Anak.Karena proposal kegiatan ini mencakup guru di semua lembaga pendidikan tersebut maka diputuskan bahwa peserta kegiatan ini harus meliputi guru di semua lembaga pendidikan tersebut secara proporsional.Adapun sisa guru yang belum mengikuti kegiatan ini akan diusulkan untuk mengikuti kegiatan sejenis yang 
akan diselenggarakan di masa-masa yang akan datang. 2)Keterbatasan dana yang tersedia dari Kemenag RI sehingga pelaksana harus berhemat-hemat dan seefisien mungkin agar kegiatan ini dapat berjalan dengan baik dan lancar.

\section{KESIMPULAN DAN REKOMENDASI}

Dari paparan laporan pelaksanaan kegiatan Penguatan Pendidikan Kesadaran Hukum Perlindungan Anak Bagi Guru Madrasah Diniyah Takmiliyah dan Pondok Pesantren Anak-Anak se Kabupaten Blora yang berbentuk penyuluhan atau kursus singkat peguatan pendidikan kesadaran hukum perlindungan anak ini dapat disimpulkan:

1) Kegiatan ini sangat dibutuhkan dan bermanfaat bagi para guru Taman Pendidikan al Quran (TPQ), guru Madrasah Diniyah (MADIN) Takmiliyah, dan para guru Pondok Pesantren Anak-Anak se Kabupaten Blora.

2) Terdapat peningkatan pemahaman dan pengetahuan para peserta kegiatan ini terhadap regulasi atau peraturan perundangan tentang perlindungan anak. Hal ini dibuktikan dengan adanya peningkatan scor tes hasil evaluasi yaitu nilai rata-rata dari 3,7 menjadi 7,9.

3) Belum semua guru di lembaga pendidikan tersebut berkesempatan mengikuti kegiatan ini karena keterbatasan dana pengabdian masyarakat.

Diharapkan masih ada kegiatan sejenis untuk tahun yang akan datang sehingga semua guru yang belum berkesempatan mengikuti kegiatan ini berkesempatan untuk bisa mengikuti kegiatan sejenis di tahun yang akan datang.

\section{DAFTAR PUSTAKA}

A.Gunawan Setiardja, Dialektika Hukum dan Moral Dalam Pembangunan Masyarakat Indonesia, Yogyakarta: Kanisius, 1990

Abu Abdillah Muhammad bin Ahmad al Qurthubhi, al Jami li Abkam al Qur an, Jilid V, Beirut: Daar al Fikr, t.thn.

Abu Ishak as Sairozi, Al Muhadzab, Juz I, Mesir: Mathba`ah al Babi al Halabi., t.thn. 
Adji Samekto, Pembangunan Berkelanjutan Dalam Tatanan Sosial Yang Berubah, Jurnal Hukum Progresif, Volume 1 Nomor 2, Oktober 2005, Program Doktor Ilmu Hukum Universitas Diponegoro Semarang

Adriaan Bedner, Administration Courts in Indonesia: A Socio-legal Study, Belanda: Leiden University, 2000

Al Dardiri, al Syarh al Kabir Hasiyah Dasuki, Jilid III, Mesir: Al Babi al Halabi, t.thn.

Al Dardiri, Al Syarh al Kabir Hasyiyah Dasuki, Jilid III,Mesir: Matba`ah al Babi al Halabi, t.thn.

Al Imam Jalaluddin al Mahaly dan Jalaluddin as Suyuthi, Tafsir al Qur'an al Karim, Juz I, Beirut: Daar al Fikr, 1998

Al Syarbini al Khatib, Mughni al Mubtaj Syarh al Minhaj, Juz II, Mesir: Mathba ah al Babi al Halabi., t.thn.

Andi Hamzah, Asas-Asas Hukum Pidana, Jakarta: Rineka Cipta, 1991

Barda Nawawi Arief, Kapita Selekta Hukum Pidana, Bandung: Citra Aditya Bakti, 2003

Esmi Warassih, Basis Sosial Hukum: Pertautan Ilmu Pengetabuan Hukum dan Ilmu Pengetabuan Sosial (dalam Pranata Hukum, Sebuah Telaah Sosiologis), Semarang: PT Suryandaru Utama, 2005

Ibn Abidin, Hasyiyah Rad al Mukbtar ala Dur al Mukbtar, Jilid V, Mesir: Al Babi al Halabi, t.thn.

Paulus Hadisuprapto, Peradilan Restoratif: Model Peradilan Anak Indonesia Masa Datang, Pidato Pengukuhan Guru Besar Fakultas Hukum Universitas Diponegoro, Semarang, 18 Februari 2006

Philippe Nonet Dan Philip Selznick, Law and Society in Transition Toward Responsive Law, diterjemahkan menjadi Hukum Responsif Pilihan di Masa Transisi, Jakarta: Huma, 2003

Wahbah al Zuhayli, Fiqh Islam wa Adillatuh, Beirut: Daar al Fikr, 1999

Yusriyadi, Strategi Pembangunan Nasional Bidang Hukum Era Orde Baru (Analisis Teoritik Tentang Kebijakan dan Implikasinya Terhadap Penyelenggaraan Hukum di Indonesia), Jurnal Masalah-Masalah Hukum Fakultas Hukum Universitas Diponegoro, Edisi VIII Januari-Maret 2000 